The Brock Review Volume 12 No. 1 (2011)

(C) Brock University

\title{
The Myth of “Animal Rights Terrorism”
}

John Sorenson

\begin{abstract}
Animal rights advocacy is frequently presented as being linked with terrorism. This paper questions that linkage, suggests that accusations of violence are greatly exaggerated and argues that the terrorist image is the product of corporate propaganda. The paper examines some of the main institutional sources of such propaganda.
\end{abstract}

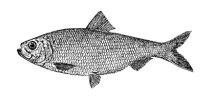

\section{Addressing Serious Issues}

The prevention of terrorism is a serious matter, especially if we look to the original use of the term to describe violence conducted by states against civilians, as in the Reign of Terror during the French Revolution. There is no shortage of significant examples from recent times: aerial bombing of cities and civilians in WW2, notably the use of atomic bombs on Hiroshima and Nagasaki, the US campaign against Cuba from 1959 to the present, US-backed coups in Guatemala in 1954, Brazil in 1964, Chile in 1973 and support for dictators and death squads throughout Latin America, US efforts to depose the Sandinista government in Nicaragua, including mobilization of a proxy army, assistance with anti-Communist massacres in Indonesia in 1965, and support for other murderous regimes elsewhere. If we limit the scope to terrorist activities by non-state actors, and focus on those committed by groups opposed to the foreign policies of western states, we still find many serious crimes from recent years: the July 2010 bombings at the Kyadondo Rugby Club and the Ethiopian Village restaurant in Kampala, the 2002 and 2005 Bali bombings, the 2004 Madrid train bombings, the 2001 World Trade Center bombing, all attributed to Islamist groups such as al Qaeda, Jemaah Islamiyah and al Shabab. In all of these cases, we see that terrorism involves the murder of innocent victims. Indeed, Chalecki points out that "the violent death of unsuspecting people" in events such as hijacked airliners crashing into the World Trade Center is what comes to most people's minds in association with the word "terrorism." Similarly, Schmid cites the communicative aspect of 
murderous violence as the central aspect of terrorism. ${ }^{2}$ The US Department of State's Office of the Coordinator for Counterterrorism emphasizes "life threatening attacks" in its definition of terrorism as "politically-motivated violence perpetrated against noncombatant targets by subnational groups or clandestine agents." 3 However if we turn from these serious cases to the topic at hand, concerning "animal rights terrorism," we find nothing comparable. Indeed, I suggest that "animal rights terrorism" is the creation of industries that profit from the exploitation of animals.

\section{Animal Exploitation Industries}

These industries are responsible for hideous suffering and premature deaths of billions of individual beings. The scale and the degree of suffering endured by nonhuman animals at our hands are scarcely conceivable. These industries not only inflict agonies and death on individual animals but devastate the environment, destroying the habitat of other animals, leading to extinction of entire species, as well as endangering the future of human life, through pollution of air, soil and water, global warming, production of new pathogens and global pandemics (in addition to epidemic levels of obesity and a host of serious health threats among those who consume animals as food). Animal activists raise serious questions about these issues and in doing so challenge the financial interests of these industries.

To meet these challenges, industries mobilize to delegitimize, marginalize and demonize their critics. Those who profit from exploitation of animals construct narratives to justify their power over others and to make exploitation of other beings seem natural, normal and acceptable. Anti-animal rights propaganda draws on a wide range of support including farmers, hunters, ranchers, the pet industry, circuses, rodeos and other forms of animal-exploitation-based entertainment, the fashion industry and dealers in fur and leather, restaurants and grocery chains, and major corporations in the agribusiness, biomedical, pharmaceutical, and vivisection industries, as well as the military. Despite their varied interests, all these voices agree on what they consider their right to exploit animals and create a chorus of anti-animal rights propaganda.

In order to make animal exploitation seem acceptable rather than cruel, foolish and murderous, industries must present the violence they conduct against animals in a better light. Corporations and their hired public relations experts work to recreate reality by shaping public discourse. Industry propaganda normalizes exploitation while presenting critics as dangerous and irrational. One propaganda tactic is to portray industry as the real protectors of animals through a discourse of "animal welfare." Another tactic is to portray activists as extremists, fanatics and, 
increasingly, as terrorists. In order to present their critics as irrational, industry propaganda depicts animal activists as "anti-human," despite the fact that the animal rights movement historically has been associated with concern for other social justice issues of direct concern to humans, such as the movement for women's rights, anti-slavery, and human rights generally. Corporate managers understand that depicting activists as terrorists is preferable to recognizing them as serious critics with identifiable goals supported by rational arguments that would have to be acknowledged and answered.

\section{Animal Rights "Violence"}

Propaganda against animal rights focuses on "violence" committed by activists. This masks far more extensive violence conducted by animal-exploitation industries on a massive scale: intensive breeding, warehousing and killing of animals in factory farms and slaughterhouses, under appalling conditions, and horrifying torture in vivisection laboratories. These violent practices are normalized, accepted as industry standards and legally permitted. Just as powerful states engage with impunity in actions that are condemned as terrorism and punished with military force when committed by others, so do we accept the most hideous atrocities when the victims are animals; it is simply prejudice to denounce violence only when it affects humans.

Industry propaganda consistently describes activists as "extremists" who use violence to achieve their ends. Unlike terrorists who deliberately target innocent people, such as in the 2005 London public transit bombings that killed 52 and injured 700, most animal activists engage in legal activities such as leafleting, demonstrations, and vegan potluck dinner events. Activists use various strategies, including vegetarian advocacy, humane education, boycotts, media campaigns, protests, undercover investigations of factory farms, slaughterhouses and laboratories and open rescues in which activists do not conceal their identities while removing animals from horrifying conditions. Only a few activists engage in illegal actions and many of those acts are not "violent" at all but consist of offences such as trespassing. Even when activists engage in illegal practices, much of this consists of rescuing animals from situations where they will be harmed or killed. Most people agree that animals should not be subjected to unnecessary suffering and consider it praiseworthy to rescue them from such situations, no matter who it is that inflicts such suffering. We feel instinctive sympathy for animals in pain and can empathize with those who rescue them. Indeed, when Sarah Whitehead and three other activists were arrested in 2006 for rescuing birds, dogs, rabbits and 
rodents from Philip Porter's pet-shop breeding operation in Sussex, Judge John Sessions refused to sentence them to prison or to order compensation to Porter because he recognized that the conditions in which the animals were kept were appalling. ${ }^{4}$ Many felt it was unjust when another judge sentenced Whitehead to a two-year prison sentence in 2008 for rescuing an abused dog from a garden where he was kept muzzled in a cage and beaten regularly.

Some activists have damaged property but much of this is minor, such as breaking locks or windows to gain entry to rescue animals. Other forms of property damage consist of such things as gluing locks or spray-painting slogans. In an even smaller number of cases, activists have damaged equipment used to harm or kill animals. However, it is arguable that this does not constitute violence. Philosopher Mark Rowlands, for example, argues that one cannot be violent towards inanimate objects, only towards living beings. ${ }^{5}$ Even if one thinks property destruction constitutes violence, it seems that the ends are commendable: the prevention of suffering.

While animal activists have not directed violence against humans, some have engaged in intimidation. Some of these activities are illegal and undoubtedly have been unpleasant for those who were targeted. However, it does not seem appropriate to equate activities such as sending of black faxes to companies involved in vivisection or even demonstrations at vivisectors' homes with the deliberate mass murder of innocent people at a restaurant or sports bar, or setting off car bombs in crowded markets with the intent to kill as many passers-by as possible. With very few exceptions, animal activists have not engaged in violence against humans. Even if we follow the lead of industry lobbyists and propagandists and ignore the vast majority of actions taken by animal activists and focus on a small number of illegal actions, we still find little to justify efforts to brand these as "terrorism." Unlike Al-Qaeda or white supremacist militias, which deliberately target and kill humans, the Animal Liberation Front (considered one of the most extreme expressions of animal advocacy) holds as one of its key principles that no harm should be done to animals, including humans, in the course of ALF actions. These principles contrast with the attitudes of actual terrorists such as, for example, white supremacist Timothy McVeigh who detonated his truck bomb at the Alfred P. Murrah Federal Building in Oklahoma City in 1995, killing 168 people, including young children at a day-care, and wounding hundreds more; afterwards, McVeigh dismissed the deaths as "collateral damage." 


\section{The Terrorism Label}

Propagandists use the language of "terrorism" to compare those who act on behalf of animals to those who commit mass murder and thus to automatically delegitimize them. No matter how noble their motives, how rational their arguments or how much their actions are congruent with what many people claim to believe, applying the "terrorist" label to activists places them outside acceptable moral boundaries. This also serves to make excessive force and diversion of resources to address the threat seem necessary.

Industry propagandists, their lobbyists and right wing think tanks feel free to make the most outrageous claims about the animal rights movement, unburdened by any need to provide evidence. For example, after the 2001 destruction of the World Trade Center, industry propagandists made frequent comparisons between animal activists and al-Qaeda; the anti-environmentalist American Policy Center even suggested that Islamists and ecoterrorists were collaborating to destroy America. Industry propagandists exaggerate violence committed by activists and increasingly use the term "terrorism" to demonize them. In its "Report to Congress on the Extent and Effects of Domestic and International Terrorism in Animal Enterprises," The Physiologist uses a very "broad, inclusive" definition of the term. The authors note the FBI's definition, already quite broad:

the unlawful use of force or violence against persons or property to intimidate or coerce a government, the civilian population, or any segment thereof, in furtherance of political or social objectives. ${ }^{6}$

The Animal Enterprise Protection Act "characterizes terrorism as physical disruption caused to the functioning of an animal enterprise." ${ }^{77}$ However, even these definitions are not broad enough for The Physiologist's authors, who consider "a wider range of activities than is covered by either the Act or FBI's definition of terrorism." ${ }^{8}$ These definitions contrast with those of ALF supporters, however, who do not consider the rescue of animals from dangerous conditions or property damage to be violence, let alone terrorism. They also reject the idea that animals are property, owned by the enterprises that exploit them, arguing that animals have their own interests and right to life.

The Physiologist emphasizes the dangers of animal rights "terrorism." One way of doing this is by omitting key aspects of the ALF guidelines, which they quote only in part:

to liberate animals from places of abuse, i.e. laboratories, factory farms, fur farms, etc, and place them in good homes where they may live out their natural lives, free from suffering to inflict economic damage to those who profit from the misery and exploitation of animals; and to reveal the horror and atrocities committed against animals behind locked doors ${ }^{9}$ 
In fact, the ALF guidelines are as follows:

1. To liberate animals from places of abuse, i.e. laboratories, factory farms, fur farms, etc, and place them in good homes where they may live out their natural lives, free from suffering.

2. To inflict economic damage to those who profit from the misery and exploitation of animals.

3. To reveal the horror and atrocities committed against animals behind locked doors, by performing non-violent direct actions and liberations.

4. To take all necessary precautions against harming any animal, human and nonhuman. ${ }^{10}$

Clearly, The Physiologist deliberately distorts the ALF's philosophy, tactics and goals by deleting the words "by performing non-violent direct actions and liberations" from the third guideline and by omitting the fourth guideline entirely. ${ }^{11}$ This distorts the ALF's approach in very significant ways, characterizing it as a violent group ready and willing to harm humans to help other animals. The intended effect is to promote a negative image of animal activism by concealing its non-violent principles.

Although the anonymous authors of The Physiologist emphasize the danger of "terrorism" their own data suggest that this is an exaggeration. Reviewing 313 actions from 1977 to 1993, they note that the "most common" of these only constitute "minor vandalism" such as graffiti, broken windows and glued locks. These account for almost half the actions. ${ }^{12}$ The second most common form of "extremist incident" is the "theft or release of animals." "The Physiologist acknowledges that "most extremist animal rights-related acts continue to be small-scale and fairly haphazard.", Only 26 of the 313 incidents are designated as "major vandalism" that the FBI categorizes as "domestic terrorism."15 Furthermore, The Physiologist finds "no evidence ... [of] ... any operational, logistical or financial connections" of ALF groups internationally. ${ }^{16}$ The Physiologist also notes considerable public sympathy for animal rights, which they describe as now a "mainstream" movement with hundreds of thousands of supporters and at least 7,000 organizations in the US alone. ${ }^{17}$

Typically in discussions of so-called "eco-terrorism" actions of animal activists and environmentalists are lumped together in chronologies of events. This overlooks philosophical disagreements between animal and environmental activists. Most animal activists probably have concern for the environment, recognizing that protection of habitat is necessary to protect endangered species. However, many environmentalist groups do not endorse animal rights and in fact denounce animal activism as a sentimental concern of misguided urban types. Opponents of 
both animal and environmental activists, however, find it very convenient to merge these movements together, since it helps to present their opponents as larger and more monolithic.

\section{Corporate Front Groups in the USA}

Nevertheless, corporate propagandists and lobby groups pushed the ecoterrorism label and used it to demand stronger laws to specifically protect animal exploitation industries. These industries channel millions of dollars to public relations firms, lobbyists and front groups to create and disseminate anti-animal rights propaganda and to influence government to create laws to silence their critics (as well as giving money directly to government officials to purchase their services.) For example, in 2010 pharmaceutical corporations spent at least \$135 million and agribusiness \$35 million on lobbying in the U.S. ${ }^{18}$

One influential corporate front group is the Center for Consumer Freedom (CCF). The CCF is a vigorous campaigner for repressive laws against animal activists, while asserting that it is defending consumer choice and promoting common sense about the use of animals. The CCF originated as the Guest Choice Network, established in 1985 by Richard Berman with funding from Philip Morris tobacco company with the objective of uniting tobacco, food and restaurant industries against anti-smoking, anti-drinking and anti-meat campaigns designed to improve public health. The GCN became the CCF in 2002, with Berman claiming that so-called anti-consumer activists were escalating their assault on personal freedom and that a more militant pro-consumer approach was needed. Financial backing expanded to include other major corporations, particularly those in the food, alcohol and restaurant industries, such as Anheuser-Busch, Brinker International, Cargill, CocaCola, HMSHost Corp, Monsanto, Pilgrim’s Pride, RTM Restaurant Group, Smithfield Foods, Tyson Foods and Wendy's, among others. The CCF is a front group for these corporations and runs negative campaigns against their critics. Thus, the CCF opposed unionization, minimum wage legislation, anti-drunk driving legislation, smoking bans and warning labels on food while rejecting health concerns about alcohol, antibiotic use for livestock, genetic engineering, mad cow disease, meat, mercury levels in fish, obesity, pesticides, salmonella poisoning and tobacco. The CCF opposes "Big Brother government" and claims to promote individual choice. Berman's widelyquoted strategy is to "shoot the messenger" and the CCF and its related organizations and websites produce attacks on groups such as the Centers for Disease Control, Greenpeace, the Humane Society of the United States, Mothers Against Drunk Driving and PETA. Especially in the case of animal welfare groups, the CCF alleges that while these groups claim to act within the law they are, in 
reality, supporters of terrorists. For example, the CCF ran a print advertising campaign (archived on its website) denouncing "PETA's Fiery Links to Arsonists." The advertisement features a large photograph of a burning building and asserts that PETA has given over $\$ 100,000$ to "convicted arsonists and other violent criminals" and, thus, is "not as warm and cuddly as you thought."19

Berman runs over a dozen industry-funded, tax-exempt front groups and holds various positions within all of them. He shifts funds between various organizations he has created, hiring his own public relations and lobbying firm to do research and channeling the money into his own pocket, which led Citizens for Responsibility and Ethics in Washington to call upon the Internal Revenue Service to revoke the CCF's tax-exempt status. In addition to working on behalf of specific corporations, Berman provides propaganda for capitalism itself through the Center for Union Facts, the Employment Freedom Action Committee, the Employment Policies Institute and the First Jobs Institute.

Corporate funders benefit from various CCF campaigns. For example, the CCF's anti-union campaigns are welcomed by Smithfield Foods, which strongly opposed unionization in its plants, but Smithfield is also the world's largest "producer" of pig-flesh, as well as "producing" significant quantities of cow-flesh, so it also benefits from the CCF's attacks on animal activists. Smithfield is notorious for its appalling environmental record, especially concerning its storage of millions of gallons of untreated fecal waste in holding lagoons in North Carolina. Humans living in the vicinity of these lagoons experienced serious health problems and complained of the overpowering stench that kept them inside their homes. In the late 1990s, Smithfield was fined $\$ 12.6$ million for violations of the Clean Water Act. Although this was a comparatively large fine, it was only a miniscule fraction of Smithfield's profits, less than 1\% of annual sales. ${ }^{20}$ In 1999 when hurricanes hit North Carolina, these lagoons overflowed and polluted rivers and waterways throughout the region. Smithfield's operations in Mexico were cited as a likely source of the 2009 swine flu epidemic. Residents living near Smithfield operations complained of health problems similar to the ones experienced in North Carolina as well as about swarms of flies at the lagoons; these flies were suspected as a vector of the disease.

As well as its opposition to unionization, lack of concern for human health and disregard for the environment, Smithfield is notorious for opposition to even minor modifications to the treatment of the animals it kills. Only after a long campaign by the Humane Society of the United States did Smithfield agree to gradual phasing out of gestation crates for pigs. For most of their lives, female pigs are confined in crates that do not allow them to turn around; they are trapped in a 
continuous cycle of artificial impregnation, gestation and farrowing until their litter sizes decrease and they are killed and replaced by other victims. In 2007 Smithfield touted its grudging agreement to slowly decrease the use of these crates as concern for what the industry calls "animal welfare" and HSUS hailed this as a major step forward by the industry; however, in 2009 Smithfield announced with less fanfare that it would no longer comply with this plan. ${ }^{21}$

The CCF promotes the idea that wealthy animal rights groups are dictating what ordinary hard-working people can do and limiting their personal choices. For example, in its television advertisement "Food police smashing your choices?", the CCF plays on a sense of entitlement and resentment about feelings of loss of personal freedom:

Everywhere you turn, someone's telling us what we can't eat. It's getting harder just to enjoy a beer on a night out. Do you always feel like you are being told what to do? $?^{22}$

"Personal choice" is the final resort of those who cannot respond to logical arguments about why they should not eat animals. Insistence that "it's a personal choice" is intended to halt further discussion, invoking sacred freedoms that must not be restricted in any way. Yet our personal choices are constantly regulated and it would be impossible to live in a situation where there were absolutely no restrictions on personal freedom. We have accepted that the slave-owner's personal choice is an insufficient justification for him to force others to work on his behalf. Similarly, the claim that one's personal choice justifies the murder of animals overlooks the personal choice those animals would make to remain alive. The CCF manipulates feelings of resentment and personal powerlessness to claim that animal activists are forcing an extremist agenda on ordinary folks. They present advocacy as intimidation and brand this terrorism, claiming that mainstream groups such as PETA are funding violent attacks.

Another corporate front group is the National Animal Interest Alliance (NAIA). The NAIA says its mission is "to promote the welfare of animals, to strengthen the human-animal bond, and safeguard the rights of responsible animal owners. ${ }^{, 23}$ However, the NAIA does nothing "to promote the welfare of animals" and, indeed, actually works against the interests of animals. ${ }^{24}$

Whereas the NAIA claims to advocate for animals, its Board members come from animal exploitation industries including circuses, rodeos, vivisection industry, dog breeders, the racing industry, and agribusiness. Their advocacy is for continued exploitation of animals, not for the animals themselves. For example, NAIA's President, Larry S. Katz, associate professor and chairman of the Animal Sciences Department at Rutgers University, works in wildlife management and "sits on 
the board of directors of the Foundation for Animal Use and Education. He is an outspoken advocate for biomedical research in print and broadcast outlets across the US, and his effectiveness in these appearances has made him a frequent target of animal rights harassment." 25 Bob Speth, pharmacy professor at Nova Southeastern University, "has written widely in support of the use of animals in biomedical research."26 Professor John Richard Schrock of the Biological Sciences department at Emporia State University "defends appropriate animal use in education."27 NAIA's National Director, Patti Strand co-authored The Hijacking of the Humane Movement: Animal Extremism in 1993, advertised as "the first US book exposing the extremism of the animal rights movement.",28

Cindy Schonholtz, NAIA Vice President is Director of Industry Outreach for the Professional Rodeo Cowboys Association, "handles government relations for the PRCA relating to animal issues leading to the defeat of numerous bans on rodeo" and works with "many other animal use industries ... to educate the public on animal welfare issues." ${ }^{29}$ She also works for Friends of Rodeo and operates the Animal Welfare Council, both supporters of the Animal Enterprise Terrorism Act (AETA, see below). The AWC represents the rodeo industry but also promotes ranching, the premarian industry, horse slaughter, the carriage horse industry and circuses. Member organizations include various rodeo and cowboy associations, carriage horse operators and circus groups such as Feld Entertainment but also Americans for Medical Progress, a pro-vivisection lobby group. Obviously, "medical progress" is even less likely to be served through rodeos than through vivisection but the AMP's willingness to join with these entertainment industries shows the convergence of interests in denouncing animal rights. AMP also collaborates with the Fur Council USA, another organization unlikely to advance medical progress, but one willing to embrace AMP's propaganda efforts to link animal activists with al-Qaeda. ${ }^{30}$

AMP was also a strong supporter of the AETA. AMP is a front group for the vivisection industry, with a Board of Directors that includes top executives from pharmaceutical and vivisection companies such as Abbott Laboratories, AstraZeneca, Charles River Laboratories, GlaxoSmithKline, Pfizer and Wyeth. These corporations have a record of violations of even the few animal welfare laws that do exist and have been the object of campaigns by animal advocates as well as various public health and consumer groups. For example, Charles River Laboratories is the world's main laboratory animal supply company. The pharmaceutical corporations that belong to AMP have been clients of Huntingdon Life Sciences, target of a major animal rights campaign. Wyeth was the subject of specific campaigns about abuse of horses in the Premarin industry. ${ }^{31}$ Four universities (Harvard, Oregon Health and Science University, University of North Carolina Chapel Hall and Tulane) on the 
AMP Board were cited by PETA as being among the "Ten Worst Laboratories," 32 and Oregon National Primate Research Center at Oregon Health and Science University was criticized by the Humane Society of the United States, In Defense of Animals, PETA, and Stop Animal Exploitation Now! for abusing primates in alcohol, nicotine, maternal deprivation and obesity studies. ${ }^{33}$ Despite the fact that other primates do not develop HIV/AIDS as humans do and that animal models are widely-criticized, the ONPRC continued to use animals in these studies as well. Whistleblowers, undercover investigations and even a 2001 report by Dr. Carol Shively, professor of pathology and psychology at Wake Forest University Medical School, who had been hired by ONPRC itself to assess the psychological condition of the Center's primate prisoners, revealed ghastly abuse of these animals, by poorly-trained technicians. ${ }^{34}$

Another NAIA board member, Gene Gregory, is president and CEO of United Egg Producers, which represents $97 \%$ of US egg production. Paul Mundell, National Director of Canine Programs for Canine Companions for Independence, is a consultant for the United States Marine Corps, helping them train dogs for military use. Board member Kenneth A. Marden, is a dog breeder, former president of the American Kennel Club and "a lifetime hunter and fly fisherman ... [who] ... actively opposes unfair dog legislation and laws proposed by animal rights fanatics in their attempts to restrict hunting, fishing and trapping [and] ... has a deep understanding of the negative consequences of animal extremism and terrorism on the lives of farmers and ranchers." ${ }^{35}$ NAIA's Advisory Board includes Sheila Lehrke from the International Professional Rodeo Association, Michael Manning, a Roman Catholic priest who "devotes much of his pastoral time defending the unique sanctity of human life from those who would place all living beings on the same spiritual plane" and retired Lt. Col. Dennis Foster, executive director of Master of Foxhounds Association "an avid horseman, [and] an internationally recognized expert in the tactics of the animal rights movement."

While claiming to promote "animal welfare," the NAIA does everything it can to undermine it by opposing animal rights, promoting anti-environmental messages, campaigning against spay and neuter programs and fighting legislation against horse slaughter and the Prevention of Farm Animal Cruelty Act. In contrast, it supports hunting, vivisection, use of animals as entertainers by "circuses, zoos, wild animal parks, aquariums, and private entertainers and foundations." ${ }^{37}$ It also supports "husbandry" practices involving mutilation of animals such as "dehorning, ... ear cropping, tail docking, and debarking of dogs, and removing the claws of cats" and endorses the breeding and raising of animals for food, fiber, and draft as well as the fur industry. ${ }^{38}$ In short, there is virtually no 
abuse of animals that the NAIA does not endorse and promote. Seemingly, for the NAIA, "animal welfare" is synonymous with "animal exploitation."

The NAIA warns against those who do protect animals:

Animal rights and environmental extremists do more than demonstrate and push radical legislation. They also use physical assaults, intimidation, vandalism, harassment, theft, property destruction and terrorism. ${ }^{39}$

The NAIA maintains what it calls "the most complete chronology of animal rights and eco- criminal acts on the Internet. ${ }^{, 40}$ No sources are cited for any incidents listed. Far from being a record of "terrorism" many of the incidents described are nonviolent, such as releasing animals from their prisons. Other incidents involve minimal damage to property, as in an example from the U.K. in March 2010 in which "Hunt saboteurs claim to have removed signs advertising hunt point-to-points and paint-stripped hunters' cars."41 Other minor acts of vandalism include spray-painting graffiti, gluing locks and breaking windows. Some incidents are unlikely to be the work of animal or environmental activists:

February 27, 2010 Monza, Italy: Oil was released into the Po river, after tanks at an abandoned refinery were tampered with. Valves were opened, and several tanks were ruptured. Authorities called the sabotage an act of environmental terrorism. ${ }^{42}$

Environmentalists would be unlikely to open valves and rupture tanks to release oil into rivers. The NAIA's description suggests this was more likely an act of thoughtless vandalism undertaken for its own sake rather than a political act. But the NAIA is determined to include every act of destruction that it can characterize as the work of its opponents.

Other corporate front groups created to combat animal advocacy are the Foundation for Biomedical Research, the National Association for Biomedical Research (NABR) and Policy Directions Inc. All work from the same address in Washington DC and were created by Frankie Trull to serve the vivisection industry. Trull has lobbied against even minor amendments to the Animal Welfare Act, such as a 1985 provision to provide caged dogs periodic exercise. Opposing this, Trull argued:

There are no scientific data which say any minimum exercise per day, or per week, is physiologically better. You just sleep better at night because you think if exercise is good for you, it must be good for the $\operatorname{dog}^{43}$

When the Alternative Research and Development Foundation tried to amend the Animal Welfare Act to include some consideration of mice and rats used in laboratories Trull persuaded Senator 
Jesse Helms to amend a farm subsidy bill so that "animal" would be defined to exclude rats, mice, and birds. ${ }^{44}$

On its website, the NABR warns:

In the past 20 years, the animal rights movement (ARM) has successfully manufactured a climate of public opposition to research involving animals. ${ }^{45}$

To combat public opinion, the NABR emphasizes terrorism:

According to the Federal Bureau of Investigation (FBI), the Earth Liberation Front (ELF) and its sister organization the Animal Liberation Front (ALF), were responsible for the vast majority of terrorist acts committed in the United States in the 1990 s. ${ }^{46}$

In addition to opposing legislation to protect animals, Trull was instrumental in having repressive laws passed to specifically target animal activists and to have them designated as terrorists. Trull boasts:

Two of NABR's accomplishments of which I am most proud are the passage of the 1992 Animal Enterprise Protection Act and the 2006 Animal Enterprise Terrorism Act. $^{47}$

\section{The Animal Enterprise Terrorism Act}

Influential animal exploitation industries pushed for stronger legislation to stop animal activism. In 2005 Senator James Inhofe organized and chaired the Senate Committee on Environment and Public Works hearing on "Oversight on Eco-Terrorism Specifically Examining the Earth Liberation Front ("ELF") and the Animal Liberation Front ("ALF"). In his opening statement, Inhofe called the ALF and ELF "terrorists by definition" [who used] "intimidation, threats, acts of violence, and property destruction to force their opinions ... upon society" and held them accountable for damages over $\$ 110$ million in over a thousand "acts of terrorism." "48 Inhofe treats the ALF and ELF interchangeably: although it was the ELF that claimed responsibility for arson at Garden Communities' condominium construction site in San Diego, California, Inhofe calls it "the largest ALF attack in history." In Inhofe compared the ALF and ELF to al-Qaeda and claimed that, like the latter, these "terrorist" groups draw money from "mainstream activists" including PETA. Admitting that "although they have not killed anyone to date" Inhofe asserts "it is only a matter of time" until they do. ${ }^{50}$ 
Most speakers continued in the same vein. Louisiana Senator David Vitter, later notorious for his use of prostitutes, acceptance of major financial contributions from the oil industry and efforts to block the Senate from forcing BP to accept full responsibility for the cleanup of the massive oil spill in 2010, applauded Inhofe's description of the ALF as "terrorists" and described two ALF actions at Louisiana Sate University. ${ }^{51}$ In the first, in 2003, ALF activists entered a toxicology laboratory, spray-painted slogans and damaged equipment; in 2005, ALF activists rescued ten mice, painted slogans and damaged equipment. Vitter said these incidents caused "psychological harm" to vivisectors and, like Inhofe, warned "it is only a matter of time" before the ALF kills humans. ${ }^{52}$

John Lewis, Deputy Assistant Director of the FBI's Counterterrorism Division, told the Committee that "the No. 1 domestic terrorism threat is the eco-terrorism animal rights movement," identified the ALF, ELF and SHAC as "today's most serious domestic threats," stated the FBI "certainly shares your opinion that these individuals are most certainly domestic terrorists" and identified this as one of the FBI's top priorities, calling for expanded federal laws to allow them to "dismantle these movements." 53 Like Inhofe and Vitter, Lewis acknowledges that these "terrorists" have never killed a human but predicts it will happen, citing an "escalation in violent rhetoric." 54 Comparing these groups to anti-abortionists, the KKK and right wing extremists, Lewis said the ALF and ELF "are way out in front in terms of the damage they are causing."

Senator Frank Lautenberg briefly questioned Lewis about more serious violence from antiabortionists and anti-gay activists before Inhofe forced him to stop. Lewis denied that antiabortionist groups could be defined as terrorists, despite the fact that they use violence to "force their opinions on society." ${ }^{, 56}$ Anti-abortionists had murdered at least seven people in the United States and seriously wounded at least 12 others in shootings, arsons, acid attacks, and bombings prior to the time of the 2005 Hearings and another murder, along with additional attacks, followed. ${ }^{57}$ Many "pro-life" groups endorsed this. ${ }^{58}$ Comparing acts of "extremist violence" by animal rights and anti-abortion groups from 1977 to 1993, and including acts against people (murder, attempted murder, kidnapping, acid attack, assault and threats) and acts against property (bombings, arson, attempted bombings or arson, major and minor damage, theft, bomb hoaxes and kidnapping) Johnson finds a total of 1,079 incidents committed by anti-abortion activists as opposed to only 337 by animal activists. ${ }^{59}$ Of the actions against property, the second-highest number (below "minor property damage") of actions committed by animal activists is in the category of "thefts" (whereas it is in the category of "arson" for anti-abortionists) and likely refers to the rescue of animals from 
vivisection laboratories or fur farms where they are subjected to close confinement, painful procedures and prematurely killed. As noted, in other circumstances, rescuing animals from danger is regarded as praiseworthy. Of actions against people included in the table, animal activists are responsible for only threats and have committed no murder, kidnapping, acid attacks or assaults. One incident of attempted murder is noted but Johnson says no FBI information on the incident is included; possibly it was the case of Fran Trutt. ${ }^{60}$

In contrast to non-violent actions of animal activists, anti-abortion activists were responsible for violence against humans and property at a rate of three to one. ${ }^{61}$ Johnson points out that more murders, attempted murders, acid attacks, bombings, arsons and death threats were conducted by anti-abortionists after 1993 and that the FBI steadfastly refused to categorize this as terrorism. Clearly, Lewis's statements about animal activists being "way out of front” are inaccurate.

Nevertheless, the Hearing was a prelude to establishing the Animal Enterprise Terrorism Act (AETA), passed by Congress and signed into law by President George W. Bush on November 27, 2006, replacing the 1992 Animal Enterprise Protection Act (AEPA). The AEPA had been crafted by the National Association for Biomedical Research (NABR) and created the term "animal enterprise terrorism." Other instigators of the AETA included influential agribusiness and biomedical industry lobby groups such as the Animal Enterprise Protection Coalition, American Legislative Exchange Council, Foundation for Biomedical Research (FBR), NABR and the Fur Commission. However, scores of other animal exploitation groups endorsed the Act. Animal-exploitation industries guided the legislation through to its passage, assisted by politicians such as Inhofe whose services they had purchased through financial contributions and who had personal investments in industries the legislation would affect.

Inhofe has substantial personal investments in oil and gas industries, has received hundreds of thousands of dollars from chemical and forestry industries, oil and gas companies, the nuclear energy industry and their political action committees and is one of the major recipients of funding from these sources. ${ }^{62} \mathrm{He}$ consistently voted against environmental and public health safety regulations that would affect these industries. ${ }^{63}$ On September 23 2009, on C-Span's Washington Journal, Inhofe said he would fly to the UN Climate Change Conference in Copenhagen to campaign against the international consensus of scientific experts. Calling himself a "one-man truth squad," Inhofe said climate change was a "hoax" perpetrated by the UN and "the Hollywood elite." 64 In his 2010 Minority Report, Inhofe named seventeen leading scientists associated with the Intergovernmental Panel on Climate Change and the United States Global Change Research 
Program as "key players" in an international conspiracy; he said their actions violated basic ethical principles concerning publicly-funded research and federal laws and called for prosecution by the U.S. Justice Department. ${ }^{65}$ Facing pressure for corporate accountability after the 2010 BP oil spill, Inhofe blocked a bill to increase liability of oil companies responsible for spills that pollute the environment, kill thousands of animals and destroy human livelihoods. Inhofe also tried to limit the Environmental Protection Agency from regulating emissions from power plants and refineries and rolled back rules on increased fuel efficiency for automobiles manufactured from 2012-2016. ${ }^{66}$ Inhofe is a staunch defender of the cruel practices of factory farming. In turn, these industries have lauded Inhofe's services to them:

in 2008, the Oklahoma Independent Petroleum Association honoured Inhofe for 'voting consistently in the 110th Congress to protect the interests of the oil and gas industry' and in 2004 the National Association of Chemical Distributors named him "legislator of the Year" while the American Farm Bureau designates him as an official "Friend of Farm Bureau," the Oklahoma Farm Bureau gave him a "Lifetime Achievement Award" and the Oklahoma Pork Council recognized his efforts on their behalf with a "Distinguished Service Award. ${ }^{67}$

Senator Dianne Feinstein co-sponsored the bill. Although she is not directly funded by animal exploitation industries, her husband, Richard Blum, is Chairman of the Board of CB Richard Ellis Group, a real estate firm that serves the vivisection industry and associated major pharmaceutical companies: American Pharmaceutical Partners, Astra Zeneca, Bayer Pharmaceuticals, Chiron, DuPont, Eli Lilly and Company, Johnson and Johnson, Merck, Novartis, Pfizer, Schering Plough and Wyeth. ${ }^{68}$ Co-sponsors of the AETA in the House also had financial interests in the industries served by the legislation. Representative Tom Petri is funded by the dairy industry and headed the Badger Fund, a political action committee funded by American Foods Group, owner of slaughterhouses; Representative Robert Scott has investments in Johnson \& Johnson, Procter \& Gamble and Yum! Brands. ${ }^{69}$

In 2006, the AETA also received a warm welcome from the Chair of the Committee on the Judiciary, Representative James Sensenbrenner, who owns stock in major pharmaceutical, chemical, petroleum and defense industries. ${ }^{70}$ Sensenbrenner also blocked the Animal Fighting Prohibition Act, intended to increase penalties for those who engage in animal fighting activities, despite the fact it unanimously passed the Senate and had hundreds of co-sponsors (the Act was finally passed in 2007). ${ }^{71}$ Like Inhofe, Sensenbrenner is a climate change denier. After Rolling Stone magazine voted him one of the planet's worst enemies in a cover story on climate change deniers, entitled 'You Idiots!", Sensenbrenner complained "I should have been No. 1, not No. 7."72 In December 2009, as 
a member of the House Select Committee on Energy Independence and Global Warming, he wrote to Dr. Rajendra Pachauri, Chair of the Intergovernmental Panel on Climate Change, demanding that scientists named in e-mails stolen from the U.K. Climatic Research Unit be blacklisted as participants, contributors or reviewers of the IPCC's upcoming Fifth Assessment Report. ${ }^{73}$ In his statement to the Committee at the Hearing on "The State of Climate Change Science", Sensenbrenner charged that the scientists were engaged in a "massive international scientific fraud" and "scientific fascism." " Sensenbrenner was a vigorous advocate for the AETA, claiming that existing laws were inadequate and that animal activists had carried out over a thousand terrorist actions, causing millions in damages. ${ }^{75}$

Animal exploitation industries cheered the new legislation they had created. The NAIA "applaud[ed] the passage" of the AETA and National director Patti Strand said:

We are grateful to Senators Inhofe and Feinstein, and Representative Petri for introducing companion bills in the Senate and House recognizing the threat to our country posed by animal-rights extremists. ${ }^{76}$

However, animal activists and civil rights advocates said the AETA was too broad and vague, and that it did not even clearly define "animal enterprise" so that the law could be applied to any business that involves animals in some way. Penalties imposed by the AETA are out of proportion to actions covered, imposing longer sentences for nonviolent actions that cause a loss of profit to animal enterprises than for actions that cause direct harm to people. Opponents also said the AETA would have a chilling effect on legal protest in general because activists would fear being charged as terrorists. ${ }^{77}$

\section{Other Proponents of Animal Rights "Terrorism"}

In addition to those who profit directly from exploitation of animals, others have an interest in exaggerating "ecoterrorism." As Herman and O'Sullivan pointed out two decades ago, there is a large network of experts and institutions organized to produce politically-useful analyses, definitions and understandings of terrorism. ${ }^{78}$ Since then, that industry has grown substantially. The Washington Post reported that since 2001 the US has developed a defense and intelligence bureaucracy "that has become so large, so unwieldy, and so secretive that no one knows how much money it costs, how many people it employs, or whether it is making the United States safer." ${ }^{\text {79 }}$ At least 1,271 government organizations and 1,931 private companies are engaged in secret counter-terrorism, homeland security, and intelligence programs in over 10,000 locations, with 33 new building 
complexes to house these bureaucracies in Washington DC alone. ${ }^{80}$ At least 850,000 personnel with Top Secret clearances work for these agencies but thousands of other jobs are associated with them, through provision of technology, services, construction and so on. ${ }^{81}$ Clearly, these security and intelligence operations involve significant amounts of money. However, "major problems" include "lack of coordination between agencies" as well as "redundancy and overlap." 82

Just as the military requires constant production of new enemies to justify its existence and the continued inflow of public funds, so do counter-terrorism operations need a constant supply of terrorists. Promoting the menace of animal rights terrorism provides income for "experts" who advise business on ecoterrorism and sell security technology. Hundreds of millions of dollars are spent on counter-terrorism research and can provide a financial boost to universities. For example, in 2004 New Jersey Institute of Technology under Director Donald J. Sebastian was designated as the site of the New Jersey Homeland Security Technology Systems Center. Counterterrorism funding, along with military and biotechnology research brought in " $\$ 100 \mathrm{M}$ in 2010, placing NJIT in the top 10 engineering universities in the nation." ${ }^{83}$ Security organizations have a vested interest in portraying illegal actions against animal exploitation industries as terrorism rather than ordinary crimes. For example, writing for Stratfor Global Intelligence, Fred Burton says direct actions should be "categorized as terrorism because of their political motive." 84 By portraying this as terrorism, the threat to business is made to seem greater (and certainly the penalties imposed by the courts are heavier), so the role of the "expert" is made to seem more vital. Thus, headlines about direct actions typically claim, without proof, that these actions are growing more serious. For example, Scott Stewart in Stratfor's Security Weekly warns against "Escalating Violence From the Animal Liberation Front" but provides no data to show that destruction of a business selling sheep-skin products in Colorado and a leather factory and a restaurant in Utah actually represent an "escalation." 85 "Animal rights terrorism" is a growth area for security firms and organizations such as the Inkermann Group produce reports such as "The War on Eco-Terror" for industry clients. The "experts" frequently called upon by mainstream media to explain "ecoterrorism" are those such as Ron Arnold, from the Center for the Defense of Free Enterprise, a virulent critic of environmentalism and founder of the Wise Use movement, a corporate-backed anti- environmental coalition organized under the idea of property rights, and linked to militia and anti-government groups. Arnold is widely-quoted on his strategy towards environmentalists, 'We're out to kill the fuckers. We're simply trying to eliminate them. Our goal is to destroy environmentalism once and for all." 86 


\section{Influence on Government in the UK}

We can clearly see the influence of animal-exploitation industries on government policy in the case of the British pharmaceutical industry. The Association of the British Pharmaceutical Industry (ABPI) is the major pharmaceutical industry lobby group in the $\mathrm{UK}$, representing at least 75 companies that supply most of the drugs prescribed by the National Health Service (NHS). The ABPI represents industry interests and works to shape laws to benefit these companies. The pharmaceutical industry is the biggest export industry in the UK, after North Sea oil and the ABPI is one of the most powerful lobby groups in the country, exerting strong influence over policy. Also, many government officials and industry regulators have significant financial interests in the industry. ${ }^{87}$

Despite industry propaganda about dedication to saving lives, the main concern is profit. The ABPI lobbied for support to biotechnology, looser regulation of advertising of drugs, including direct marketing to consumers, opposed calls for disclosure of research data, despite the fact that this information would be of use to academics, consumer groups and public safety advocates, opposed plans to lower drug prices and opposed South Africa's plan to provide affordable AIDS medicines. ${ }^{88}$ ABRI also advocates for vivisection and stated its concerns about animal activists who challenge these practices. ${ }^{89}$

Although the Liberal Party campaigned on promises to reduce and eventually end vivisection and to establish a Royal Commission to investigate the actual need for animal research, those promises were abandoned after they were elected..$^{90}$ Instead they began closer cooperation with vivisection, biotechnology and pharmaceutical industries and stated they would support the industry by making regulation more "flexible." In November 1999 British PM Tony Blair joined CEOs of giant pharmaceutical corporations of Astra Zeneca, Glaxo Wellcome and SmithKline Beecham on the Pharmaceutical Industry Competitiveness Task Force (PICTF) "to retain and strengthen the competitiveness of the UK business environment for the innovative pharmaceutical industry." 92 The PICTF appointed Lord Sainsbury as chair of a working group to cut vivisection regulations. No animal advocacy groups were included.

Sainsbury is a billionaire, one of the UK's richest men, with investments in supermarkets and biotechnology, including the Sainsbury Laboratory. Sainbury used his wealth to buy positions of influence within the government; he gave over 11 million pounds to the Liberal Party and was rewarded by Tony Blair with an appointment to the House of Lords as Lord Sainsbury of Turville and then appointed Parliamentary Under-Secretary of State for Science in the Department of Trade 
and Industry. ${ }^{93}$ Sainsbury later resigned, following a police investigation of government corruption. ${ }^{94}$ Sainsbury's group made drastic changes to policies, supplanting responsibilities of the Home Office, and weakening existing regulations on vivisection as measures to guarantee the pharmaceutical corporations' profits. The PICTF also agreed on protection of patents and intellectual property, demonstrating support for industry's opposition to governments of underdeveloped countries' efforts to manufacture cheaper life-saving drugs. The PICTF proposed other important policy changes, including safety assessment of new drugs and drug purchases by the National Health System and advised that industry should be consulted on any new policy changes considered by the government. As pharmaceutical company executives gained unprecedented influence over government policy, corporate interests rather than public health became the key concern.

In its 2001 Final Report, PICTF warned:

the increasing complexity of the regulatory process involved in obtaining licences to carry out animal studies... and the possible implications of the new Freedom of Information Act, have meant that the UK is increasingly perceived by industry as an unfavourable environment in which to conduct research involving animals... [and] there is a danger that, as a result, research may be moved abroad. ${ }^{95}$

Government heeded ABPI's warning about inconvenient regulations: in 2004, PICTF announced that the time required to obtain approval for vivisection had fallen to its lowest level. ${ }^{96}$ In 2006 , Prime Minister Tony Blair expressed strong personal support to the industry, going as far as to write an article for The Sunday Telegraph explaining why he signed an online petition in support of vivisection. ${ }^{97}$ Blair's support for the vivisection industry included a proposed new law to exempt the industry from legal requirements to publish details of shareholders.

The PICTF also called for amendments to the Criminal Justice and Police Bill, the Malicious Communications Act and the Companies Act "to tackle harassment and intimidation by animal rights campaigners" and noted that "Amendments have subsequently been brought forth by the Government." ${ }^{\prime 98}$ In response to industry's demand for stronger legislation to silence critics, the 2001 Police and Criminal Justice Act penalized various forms of protest that were proving effective.

As well, the Association of Chief Police Officers Terrorism and Allied Matters unit created the National Coordinator Domestic Extremism to combat "domestic extremism" in England and Wales. The NCDE has an annual budget of 9million pounds and a staff of 100 police officers. ${ }^{99} \mathrm{It}$ includes three units. The National Public Order Intelligence Unit (NPOIU) provides "intelligence" on thousands of animal activists gathered by police surveillance groups called Forward Intelligence Teams and Evidence Gatherers. These spies photograph activists at public meetings, rallies and 
protests and collect detailed information for entry into national computer databases. The National Domestic Extremism Team carries out secret investigations and the National Extremism Tactical Coordination Unit (NETCU) provides information to local police for political campaigns. Although organized specifically to spy on animal activists, the NCDE does not identify any groups that it considers domestic extremists, saying this would "compromise" its investigations. ${ }^{100}$ However, according to NETCU's website:

Domestic extremism is most commonly associated with 'single-issue' protests, such as animal rights, environmentalism, anti-globalisation or anti-GM crops ...We support industry, academia and other organisations that have been targeted or could be targeted by extremists ... ${ }^{101}$

Although the website claims that NETCU and the police remain strictly impartial on the issues, this is clearly not true, as the website formerly listed several links to pro-vivisection groups such as the Coalition for Medical Progress, the Research Defense Society and the Victims of Animal Rights Extremism (these links have now been removed). However, no links to any organizations that present an anti-vivisection argument were ever listed so claims of impartiality are unconvincing and the pro-vivisection links and statements of support to industry indicate a clear bias. NETCU's main focus is animal activism and few other forms of "domestic extremism" are mentioned on their website.

The NCDE says it:

does not usually focus those who choose to protest peacefully and lawfully. The unit is mainly concerned with those who commit criminal offences in furtherance of their campaign. ... The units will have less interest in those who choose to sit down in the road or fasten themselves to gates to protest - we are mainly concerned with those who commit more serious offences. However, police forces will always need to deal with such incidents. ${ }^{102}$

While the NCDE says it does not "usually" focus on peaceful protest and is "mainly" concerned with criminals, it gives itself the mandate to monitor legal protests and suggests that significant links exist between those who protest legally and those who commit criminal acts. (This is a standard assertion by industry front groups. While regularly intoning belief in the right to dissent, they constantly strive to make dissent ineffective and to show that lawful protest hides criminal intent and associations.) Indeed, one regular task of the police is to monitor such protests, photograph activists and collect information on them as well as to infiltrate activist groups. The NCDE also monitors journalists at political events and demonstrations. ${ }^{103}$ 
Through the NCDE, police on a national basis have collected personal details of thousands of activists who have taken part in political events and protests and have stored these data on a secret network of intelligence databases, even if those activists have committed no crimes. Noting that "domestic extremism" is a term with no legal definition and has simply been invented by the police, The Guardian reports: "Senior officers say domestic extremism ... can include activists suspected of minor public order offences such as peaceful direct action and civil disobedience."104 The Guardian notes that police acknowledged that crimes associated with animal rights had been decreasing and the NCDE was branching out to spy on "anti-war and environmental groups that have only ever engaged in peaceful direct action." 105 Presumably, identifying other activists as terrorists is one means to justify the budget of organizations such as the NCDE but these groups are also considered as comparable threats to the interests of industry and as logical targets of the police mentality that sees the public as the enemy and the expression of dissent as a threat to "order" and "security."

\section{“Terrorists" Apprehended}

We may ask what sorts of terrorists have been apprehended through this legislation and increased police powers. In 2009 four activists-Adriana Stumpo, Nathan Pope, Joseph Buddenberg and Maryam Khajavi-were charged under the AETA for protesting at the homes of University of California vivisectors in 2007 and 2008. Police said they wore bandanas and wrote "Stop the Torture," "Bird Killer" and "Murder for Scientific Lies" on the pavement with chalk. ${ }^{107}$ In July 2010, a federal judge dismissed the indictment because it was too vague and because prosecutors could not specify how the activists had broken any laws. ${ }^{108}$

In June 2010 in Britain, the NPOIU classified 85-year old John Catt and his 50-year old daughter, Linda Catt, as "domestic extremists" for attending legal anti-war demonstrations in a campaign against a Brighton weapons factory operated by US-owned EDO MBM Technology. John Catt's activities at these protests consisted of making sketches of scenes he observed. The Catts have no criminal records and only engaged in legal activities:

Our activities were totally legitimate - we were not interested in non-violent direct action," said Linda . "My dad likes to sketch and I will hold a banner and shout a few things. But I'm careful about what I say. ${ }^{109}$ 
Although Canada has not enacted specific laws against animal rights activism, it provides an example of how devalued the term "terrorism" has become as those who oppose animal activists go to absurd lengths to demonize their enemies. In January 2010, Canadian Liberal MP Gerry Byrne called on the federal government to investigate U.S.-based PETA under Canada's anti-terrorism laws after activist Emily McCoy pushed a tofu-cream pie into the face of Fisheries Minister Gail Shea during a speech in Burlington, Ontario as an act of protest against the government's support for the seal hunt. Byrne, an MP for Newfoundland and Labrador, said the incident met the legal definition of terrorism:

When someone actually coaches or conducts criminal behaviour to impose a political agenda on each and every other citizen of Canada, that does seem to me to meet the test of a terrorist organization. I am calling on the Government of Canada to actually investigate whether or not this organization, PETA, is acting as a terrorist organization under the test that exists under Canadian law. ${ }^{110}$

However, PETA's president told The Canadian Press:

Mr. Byrne's reaction is a silly, chest-beating exercise ...It is unlikely to impress anyone who has a heart for animals or who is bright enough to spot the difference between a bomb and a tofu cream pie. ${ }^{111}$

For some closing insight on "animal rights terrorism," we may refer to the Statement of then-Senator, now-President Barack Obama at the 2005 Senate Committee Hearings on Ecoterrorism. Noting that there had been a "downward trend" in so-called ecoterrorist crimes, Obama suggested that those crimes should be seen in the context of the much greater number of hate crimes and environmental crimes committed by industry that resulted in worker endangerment, public health threats and environmental damage. Obama advised the Committee to "focus its attention on larger environmental threats, such as the dangerously high blood lead levels in hundreds of thousands of children" and that the Committee's time would be better spent on more serious issues. ${ }^{112}$ We would still do well to heed that advice.

\section{Notes}

${ }^{1}$ Elizabeth L. Chalecki, A New Vigilance: Identifying and Reducing the Risks of Environmental Terrorism (Oakland: Pacific Institute for Studies in Development, Environment, and Security, 2001), 3.

2 Alex P. Schmid, 'Terrorism as Psychological Warfare.' Democracy and Security 1 (2005): 138. 
${ }^{3}$ US Department of State Office of the Coordinator for Counterterrorism, "Annex of Statistical Information to Country Reports on Terrorism” (National Counterterrorism Center: 2007) http://www.state.gov/s/ct/rls/crt/2006/82739.htm) 4 Stewart Payne, "Animal activists freed over filthy breeding centre," Telegraph (August 19, 2006) http://www.telegraph.co.uk/news/1526690/Animal-activists-freed-over-filthy-breeding-centre.html ${ }^{5}$ Mark Rowlands, Animals Like Us (London: Verso, 2002), 188.

6 "Report to Congress on the Extent and Effects of Domestic and International Terrorism in Animal Enterprises," The Physiologist 36 no.6 (1993): 207, 247-259.

7 Ibid., 247.

8 Ibid.

9 Ibid., 248-249.

10 Animal Liberation Front, "The ALF Credo and Guidelines," (n.d.) http://www.animalliberationfront.com/ALFront/alf_credo.htm

11 "Report to Congress on the Extent and Effects of Domestic and International Terrorism in Animal Enterprises," 248249.

12 Ibid., 253

13 Ibid.

14 Ibid., 251

15 Ibid., 253

16 Ibid., 257

${ }^{17}$ Ibid., 248

18 Drug Discovery and Development, “Growing Pressure to Stop Antibiotics In Agriculture,” (January 4, 2010) http:/ / www.dddmag.com/news-Growing-Pressure-to-Stop-Antibiotics-In-Agriculture-10410.aspx

${ }^{19}$ Center for Consumer Freedom, "PETA's Fiery Links to Arsonists," (n.d.)

http://www.consumerfreedom.com/advertisements_detail.cfm/ad/15

${ }^{20}$ Jeff Toetz, "Boss Hog,” Rolling Stone (Feb. 14, 2007) http://www.rollingstone.com/politics/story/1

2840743 /porks_dirty_secret_the_nations_top_hog_producer_is_also_one_of_americas_worst_polluters

${ }^{21}$ Humane Society of the United States, "HSUS Exposes Inhumane Treatment of Pigs at Smithfield," (2010)

http://www.humanesociety.org/news/press_releases/2010/12/smithfield_pigs_121510.html

22 Center for Consumer Freedom, "Food Police Smashing Your Choices?” (n.d.)

http://www.consumerfreedom.com/advertisements_detail.cfm/ad/38

${ }^{23}$ National Animal Interest Alliance, "Mission Statement" http:/ / www.naiaonline.org/about/mission.htmhttp://www.naiaonline.org/about/mission.htm

24 National Animal Interest Alliance, "NAIA Board, Advisory Board, Staff, and Volunteer Staff' (n.d)

http://www.naiaonline.org/about/board.htm

25 Oregon National Primate Research Center

http://www.sourcewatch.org/index.php?title=Oregon_National_Primate_Research_Center

26 Ibid.

27 Ibid.

28 Ibid.

${ }^{29}$ Ibid.

${ }^{30}$ Simon Ward, “Media Link September 11 With Ecoterror,” Fur Commission USA: 2001. http:/ / www.furcommission.com/news/newsF03p.htm

31 People for the Ethical Treatment of Animals, "Victory! Wyeth Closes Premarin Plant," (n.d)

http://www.peta.org/features/wyeth-closes-premarin-plant.aspx

32 Sourcewatch, "Ten Worst Laboratories," (2011)

http://www.sourcewatch.org/index.php?title=Ten_Worst_Laboratories

33 Sourcewatch, "Oregon National Primate Research Centre," (2011)

http://www.sourcewatch.org/index.php?title=Oregon_National_Primate_Research_Center

${ }^{34}$ Ibid.

${ }^{35}$ National Animal Interest Alliance, "NAIA Board, Advisory Board, Staff, and Volunteer Staff."

${ }^{36}$ Ibid.

${ }^{37}$ National Animal Interest Alliance, "Policy Statement: Animals in Entertainment and Zoos," (n.d.) http://www.naiaonline.org/articles/archives/policy_animent.htm

38 National Animal Interest Alliance, "NAIA position statement: Animal husbandry practices," (n.d.) http://www.naiaonline.org/articles/archives/policy_husbandry.htm 
${ }^{39}$ National Animal Interest Alliance, "Animal rights and environmental extremists use intimidation and violence to achieve their ends,” (2010) http://www.naiaonline.org/body/articles/archives/arterror.htm

${ }^{40}$ Ibid.

${ }^{41}$ Ibid.

42 Ibid.

43 Sourcewatch, "NABR \& the Animal Welfare Act," (2011)

http://www.sourcewatch.org/index.php?title=NABR_\%26_the_Animal_Welfare_Act

44 Ibid.

${ }^{45}$ National Association for Biomedical Research, “Animal Rights Extremism” (n.d.)

http://www.nabr.org/Animal_Activism/Animal_Rights_Extremism.aspx

${ }^{46}$ National Animal Interest Alliance, "Animal Rights Extremism,” (2007)

http://www.nabr.org/Activism/AnimalRightsExtremism/tabid/407/Default.aspx

${ }^{47}$ Frankie Trull, “Thirty Years ... Time Flies!” Ask Frankie,” (September 24, 2009)

http://www.nabr.org/AboutNABR/AskFrankie/tabid/952/EntryId/10/Thirty-years-Time-Flies.aspx

${ }^{48}$ United States Senate Committee on Environment and Public Works, "Eco-terrorism Specifically Examining the Earth Liberation Front (“ELF”) and the Animal Liberation Front ('ALF')" (May 18, 2005)

http://www.rexano.org/Eco_terror_32209.pdf , 1

${ }^{49}$ Ibid., 2.

${ }^{50}$ Ibid., 3

51 Ibid., 8.

52 Ibid., 11

${ }^{53}$ Ibid., 12

54 Ibid.

55 Ibid., 15

${ }^{56}$ Ibid., 18

57 National Abortion Federation, "NAF Violence and Disruption Statistics," (2009)

http://www.prochoice.org/pubs_research/publications/downloads/about_abortion/violence_stats.pdf

58 Army of God, "Defensive Action Statement," (n.d.) http://www.armyofgod.com/defense.html

59 Dane E. Johnson, "Cages, Clinics, and Consequences: The Chilling Problems of Controlling Special-Interest

Extremism,” Oregon Law Review (2008) 86: 249-294.

${ }^{60}$ Ibid. In 1988, Trutt was charged with attempted murder after trying to place a bomb near a parking spot used by Leon Hirsch, CEO of US Surgical Corporation, producer of biomedical tools. In fact, Trutt was incited to violence by Mary

Lou Sapone, an undercover agent for Perceptions International, a security firm specializing in actions against the animal rights movement. Hirsh hired Sapone and other undercover agents to infiltrate animal rights groups and prod them to commit illegal activities. The plot to entrap Trutt was discussed at a meeting that included representatives of the federal Bureau of Alcohol, Tobacco and Firearms, the Connecticut States Attorney's office, US Surgical Corporation's security director and Perceptions International (Berlet 1991). Sapone had approached numerous other activists, all of whom rejected her incitements. Perceptions International agents pretended to befriend Trutt, suggested the bombing, paid for the equipment, and drove her to the US Surgical parking lot. Trutt was reluctant to continue and called another "friend" (also a Perceptions International agent), who encouraged her to carry out the operation.

${ }^{61}$ Ibid.

${ }^{62}$ Sourcewatch, "James M. Inhofe,” (n.d.) http://www.sourcewatch.org/index.php?title=James_M._Inhofe

63 Ibid.

${ }^{64}$ Kate Shepherd, “James Inhofe's One-Man Truth Squad,” Mother Jones (December 17, 2009)

http://motherjones.com/blue-marble/2009/12/inhofe-brings-one-man-truth-squad-0

${ }^{65}$ United States Senate Committee on Environment and Public Works, "Consensus' Exposed: The CRU Controversy," (Minority Staff, February 2010): 1.

${ }^{66}$ John M. Broder, "Inhofe and Upton: Just Say No to the E.P.A," New York Times (March 3, 2001)

http:/ /green.blogs.nytimes.com/2011/03/03/inhofe-and-upton-just-say-no-to-the-e-p-a/

${ }^{67}$ Dara Lovitz, Muzzling A Movement (New York: Lantern, 2010), 85-86.

${ }^{68}$ Ibid., $84-85$

${ }^{69}$ Ibid., 85

70 Ibid., 87

71 John Cochran, "House Judiciary Chairman Blocks Bill Against Animal Fighting," ABC News (November 14, 2006) http://abcnews.go.com/Politics/ story?id=2652909\&page=1 
72 Myers, Jim, 2010. Inhofe on 'Enemies' list.” Tulsa World. January 13.

http:/ / www.tulsaworld.com/news/article.aspx?subjectid=16\&articleid=20100113_16_A1_OlhmeJ156867

${ }^{73}$ Rick Piltz, "Sensenbrenner IPCC witch-hunt: Attempt to blacklist climate scientists must be rejected," Climate Science W atch (December 9, 2009) http:/ /www.climatesciencewatch.org/2009/12/09/sensenbrenner-ipcc-witch-hunt-attemptto-blacklist-climate-scientists-must-be-rejected/

74 “Sensenbrenner to Tell Copenhagen: No Climate Laws Until ‘Scientific Fascism’ Ends,” Fox News (December 9, 2009) http://www.foxnews.com/politics/2009/12/09/sensenbrenner-climate-fascism/

75 Will Potter, “The Green Scare," Vermont Law Review 33 (2009): 682

${ }^{76}$ National Animal Interest Alliance, "Voices of Reason Win the Day AETA Awaits President's Signature" (2006) http://www.naiaonline.org/library/AETA.htm

77 Potter

${ }^{78}$ Edward S. Herman and Gerry O’Sullivan, The Terrorism Industry (New York: Pantheon, 1989)

${ }^{79}$ Dana Priest and William M. Arkin, “Top Secret America” Washington Post (July18-19, 2010)

http://projects.washingtonpost.com/top-secret-america/

${ }^{80}$ Ibid.

81 Ibid.

82 Ibid.

${ }^{83}$ New Jersey Institute of Technology, "Donald H. Sebastian” (n.d.) http://www.njit.edu/news/experts/sebastian.php; Judy Peet, "NJIT homeland security center studies groundbreaking anti-terrorism technology," NJ.com (June 12, 2010) http://www.nj.com/news/index.ssf/2010/06/njit_scientists_homeland_secur.html

${ }^{84}$ Fred Burton, “Direct Action’ Attacks: Terrorism by Another Name?” Stratfor Global Intelligence (May 23, 2007) http://www.stratfor.com/direct_action_attacks_terrorism_another_name

85 Scott Stewart, "Escalating Violence From the Animal Liberation Front," Security Weekly (July 29, 2010)

http://www.stratfor.com/weekly/20100728_escalating_violence_animal_liberation_front

${ }^{86}$ David Helvarg, The War Against the Greens (Boulder: Johnson, 2004), 7.

${ }^{87}$ Corporate Watch, "The Association of the British Pharmaceutical Industry," (2003)

http://www.corporatewatch.org/?lid=332

88 Ibid.

${ }^{89}$ Ibid.

90 SPEAK, "Bad Politics" (n.d.) http://speakcampaigns.org/sitepages.php?a=5

91 "Lord Sainsbury insists 'cash for honours' not behind his resignation," Daily Mail (November 10, 2006) http:/ / www.dailymail.co.uk/news/article-415740/Lord-Sainsbury-insists-cash-honours-resignation.html

92 Department of Health, "Pharmaceutical Industry Competitiveness Task Force," (n.d.)

http://www.dh.gov.uk/ab/Archive/PICTF/DH_090491.

93 “ $£ 2.5 \mathrm{~m}$ Labour donation attacked as 'corruption,” The Guardian (April 1, 2003)

http://www.guardian.co.uk/politics/2003/apr/01/labour.uk; Corporate Watch, "New Science Minister Another Industry Crony," (n.d.) http:/ / www.corporatewatch.org/?lid=2224; Lobbywatch, "Lord David Sainsbury," (n.d.) http:/ / www.lobbywatch.org/profile1.asp?PrId=116

94 Graeme Wilson, "Sainsbury Quits 'in Anger over Loan Affair,” The Telegraph (November 11, 2006)

http:/ / www.telegraph.co.uk/news/uknews/1533851/Sainsbury-quits-in-anger-at-loans-affair.html

${ }^{95}$ Department of Health and the Association of the British Pharmaceutical Industry, Executive Summary, Pharmaceutical Industry Competitiveness Task Force, Final Report - March 2001 (jointly published by the Government and the ABPI, 2001) http://www.rieti.go.jp/jp/events/bbl/data/pictf.pdf

${ }^{96}$ Department of Health and the Association of the British Pharmaceutical Industry, Pharmaceutical Industry Competitiveness Task Force Competitiveness and Performance Indicators (2004) http:/ /www.advisorybodies.doh.gov.uk/pictf/2004Indicators.pdf

97 Tony Blair, "Time to Act Against Animal Rights Protestors," The Telegraph (May 14, 2006) http://www.telegraph.co.uk/news/uknews/1518328/Tony-Blair-Time-to-act-against-animal-rights-protesters.html

${ }_{98}$ Department of Health and the Association of the British Pharmaceutical Industry, Pharmaceutical Industry Competitiveness Task Force, Final Report - March 2001 (jointly published by the Government and the ABPI, 2001)

http://www.rieti.go.jp/jp/events/bbl/data/pictf.pdf, 55-56.

${ }^{99}$ Rob Evans, Matthew Taylor, Afua Hirsch and Paul Lewis, "Rein in undercover police units, says former DPP," The Guardian (January 13, 2011) http://www.guardian.co.uk/environment/2011/jan/13/mark-kennedy-undercover-policeacpo

100 Association of Chief Police Officers, "NCDE National Coordinator Domestic Extremism,” (n.d) http://www.acpo.police.uk/NationalPolicing/NCDENationalCoordinatorDomesticExtremism/FAQ.aspx 
${ }^{101}$ National Extremism Tactical Coordination Unit, “About NETCU,” (n.d.) http://www.netcu.org.uk/about/about.jsp 102 Association of Chief Police Officers, "Frequently Asked Questions," (n.d.) http://www.acpo.police.uk/NCDE/FAQ.aspx

103 Paul Lewis, Marc Vallee and John Domokos, "Under surveillance: police target environmental protesters and journalists," The Guardian (March 6, 2009) http://www.guardian.co.uk/uk/video/2009/mar/06/police-surveillanceclimate-camp-journalists

104 Paul Lewis, Rob Evans and Matthew Taylor, "Police in $£, 9 \mathrm{~m}$ scheme to log 'domestic extremists," The Guardian (October 25, 2009) http://www.guardian.co.uk/uk/2009/oct/25/police-domestic-extremists-database

105 Ibid.

106 Ibid.

${ }^{107}$ Emma Marris, “Animal rights 'terror' law challenged,” Nature 466 (2010): 424. Retrieved from: http://www.animalliberationpressoffice.org/Media/Media_10-07-20_aeta4chargesdropped_nature.htm 108 Ibid.

109 Paul Lewis and Rob Evans, "Peace campaigner, 85, classified by police as 'domestic extremist," The Guardian (June 25, 2010) http://www.guardian.co.uk/uk/2010/jun/25/peace-campaigner-classified-domestic-extremist 110 John Lewandowski, "Is a pie in the face a terrorist act?" Globe and Mail (January 26, 2010) http://www.theglobeandmail.com/news/politics/is-a-pie-in-the-face-a-terrorist-act/article1444392/ 111 Ibid.

112 Barack Obama, "Statement of Senator Barack Obama Oversight on Eco-terrorism specifically examining the Earth Liberation Front (ELF) and the Animal Liberation Front (ALF)." Washington, D.C.: U.S. Senate Committee on

Environment \& Public Works, 2005. http://www.iwar.org.uk/cyberterror/resources/eco-terror/obama.htm

\section{Bibliography}

“ $£ 2.5 \mathrm{~m}$ Labour donation attacked as 'corruption.” The Guardian (April 1, 2003) http://www.guardian.co.uk/politics/2003/apr/01/labour.uk

Animal Liberation Front. "The ALF Credo and Guidelines.” (n.d.) http://www.animalliberationfront.com/ALFront/alf_credo.htm

Army of God. "Defensive Action Statement." (n.d.) http://www.armyofgod.com/defense.html Association of Chief Police Officers. "NCDE National Coordinator Domestic Extremism." (n.d.) http://www.acpo.police.uk/NationalPolicing/NCDENationalCoordinatorDomesticExtremi sm/FAQ.aspx

--.. "Frequently Asked Questions." (n.d.) http://www.acpo.police.uk/NCDE/FAQ.aspx

Berlet, Chip. 1991. Attacks On Greenpeace and Other Ecology Groups. Somerville: Political Research Associates. (August 22, 1991) http://www.publiceye.org/liberty/greenspy.html

Blair, Tony. "Time to Act Against Animal Rights Protestors." The Telegraph (May 14, 2006) http://www.telegraph.co.uk/news/uknews/1518328/Tony-Blair-Time-to-act-againstanimal-rights-protesters.html)

Broder, John M. "Inhofe and Upton: Just Say No to the E.P.A." New York Times (March 3, 2001) http://green.blogs.nytimes.com/2011/03/03/inhofe-and-upton-just-say-no-to-the-e-p-a/

Burton, Fred. “'Direct Action' Attacks: Terrorism by Another Name?” Stratfor Global Intelligence (May 23, 2007) http://www.stratfor.com/direct_action_attacks_terrorism_another_name

Center for Consumer Freedom. "PETA's Fiery Links to Arsonists." (n.d.) http://www.consumerfreedom.com/advertisements_detail.cfm/ad/15 
---. "Food Police Smashing Your Choices?" (n.d.) http://www.consumerfreedom.com/advertisements_detail.cfm/ad/38

Chalecki, Elizabeth L. A New Vigilance: Identifying and Reducing the Risks of Environmental Terrorism. Oakland: Pacific Institute for Studies in Development, Environment, and Security, 2001.

Cochran, John. "House Judiciary Chairman Blocks Bill Against Animal Fighting." $A B C$ News. (November 14, 2006) http://abcnews.go.com/Politics/story?id=2652909\&page=1

Corporate Watch. "New Science Minister Another Industry Crony.” (n.d.) http:/ / www.corporatewatch.org/?lid=2224

---. "The Association of the British Pharmaceutical Industry," (2003) http:/ /www.corporatewatch.org/?lid=332

Department of Health and the Association of the British Pharmaceutical Industry. Pharmacentical Industry Competitiveness Task Force, Final Report - March 2001. Department of Health and the Association of the British Pharmaceutical Industry, 2001.

---. Executive Summary, Pharmaceutical Industry Competitiveness Task Force, Final Report - March 2001. Department of Health and the Association of the British Pharmaceutical Industry, 2001.

---. Pharmaceutical Industry Competitiveness Task Force Competitiveness and Performance Indicators. Department of Health and the Association of the British Pharmaceutical Industry, 2004.

Drinkard, Jim. Untitled AP report. (April 6, 1986) http://www.primatelabs.com/archives.php

Drug Discovery and Development. "Growing Pressure to Stop Antibiotics In Agriculture." (January 4, 2010) http:/ /www.dddmag.com/news-Growing-Pressure-to-Stop-Antibiotics-InAgriculture-10410.aspx

Evans, Rob, Matthew Taylor, Afua Hirsch and Paul Lewis. "Rein in undercover police units, says former DPP." The Guardian (January 13, 2011)

http://www.guardian.co.uk/environment/2011/jan/13/mark-kennedy-undercover-policeacpo

Helvarg, David. The War Against the Greens. Boulder: Johnson, 2004.

Herman, Edward S. and Gerry O'Sullivan. The Terrorism Industry. New York: Pantheon, 1989.

Humane Society of the United States. "HSUS Exposes Inhumane Treatment of Pigs at Smithfield." (2010) http://www.humanesociety.org/

Johnson, Dane, E. "Cages, Clinics, and Consequences: The Chilling Problems of Controlling Special-Interest Extremism.” Oregon Law Review 86 (2008): 249-294.

Lewandowski, John. "Is a pie in the face a terrorist act?" Globe and Mail (January 26, 2010) http://www.theglobeandmail.com/news/politics/is-a-pie-in-the-face-a-terroristact/article1444392/

Lewis, Paul and Rob Evans. "Peace campaigner, 85, classified by police as 'domestic extremist." The Guardian (June 25, 2010) http://www.guardian.co.uk/uk/2010/jun/25/peace-campaignerclassified-domestic-extremist

---., Rob Evans and Matthew Taylor. "Police in $f, 9 \mathrm{~m}$ scheme to log 'domestic extremists'." The Guardian (October 25, 2009) http://www.guardian.co.uk/uk/2009/oct/25/policedomestic-extremists-database

---., Marc Vallee and John Domokos. "Under surveillance: police target environmental protesters and journalists." The Guardian (March 6, 2009) http://www.guardian.co.uk/uk/video/2009/mar/06/police-surveillance-climate-campjournalists 
Lobbywatch. "Lord David Sainsbury." (n.d.) http://www.lobbywatch.org/profile1.asp?PrId=116

"Lord Sainsbury insists 'cash for honours' not behind his resignation." Daily Mail (November 10, 2006) http://www.dailymail.co.uk/news/article-415740/Lord-Sainsbury-insists-cashhonours-resignation.html

Lovitz, Dara. Muzzling A Movement. New York: Lantern, 2010.

Marris, Emma. “Animal rights 'terror' law challenged.” Nature 466 (2010): 424.

Myers, Jim. 'Inhofe on 'enemies' list.” Tulsa World (January 13, 2010) http://www.tulsaworld.com/news/article.aspx?subjectid=16\&articleid=20100113_16_A1_ OlhmeJ156867\&archive $=$ yes

National Abortion Federation. "NAF Violence and Disruption Statistics." (2009) http://www.prochoice.org/pubs_research/publications/downloads/about_abortion/violenc e_stats.pdf

National Animal Interest Alliance. "Mission Statement.”(n.d.) http://www.naiaonline.org/about/mission.htmhttp://www.naiaonline.org/about/mission.h tm

---. "NAIA position statement: Animal husbandry practices." (n.d.) http:/ /www.naiaonline.org/articles/archives/policy_husbandry.htm

---. "Policy Statement: Animals in Entertainment and Zoos." (n.d.) http://www.naiaonline.org/articles/archives/policy_animent.htm

---. "NAIA Board, Advisory Board, Staff, and Volunteer Staff." (n.d.) http://www.naiaonline.org/about/board.htm

---. "Voices of Reason Win the Day AETA Awaits President's Signature." NALA Newsletter. (November 20, 2006) http://www.naiaonline.org/library/AETA.htm

---. "Animal rights and environmental extremists use intimidation and violence to achieve their ends." (2010) http:/ / www.naiaonline.org/body/articles/archives/arterror.htm

National Association for Biomedical Research, n.d.. "Animal Rights Extremism." http://www.nabr.org/Animal_Activism/Animal_Rights_Extremism.aspx

National Extremism Tactical Coordination Unit. “About NETCU.” (n.d.) http://www.netcu.org.uk/about/about.jsp

New Jersey Institute of Technology. "Donald H. Sebastian" (n.d.) http://www.njit.edu/news/experts/sebastian.php

O'Brien, Michael. "Inhofe to travel to climate summit as 'one-man truth squad." (September 9, 2009) http://thehill.com/blogs/blog-briefing-room/news/59979-inhofe-to-travel-toclimate-summit-as-one-man-truth-squad

Obama, Barack. "Statement of Senator Barack Obama Oversight on Eco-terrorism specifically examining the Earth Liberation Front (ELF) and the Animal Liberation Front (ALF)." (Washington, D.C.: U.S. Senate Committee on Environment \& Public Works, 2005) http://www.iwar.org.uk/cyberterror/resources/eco-terror/obama.htm

Payne, Stewart. "Animal activists freed over filthy breeding centre.” The Telegraph (August 19, 2006) http://www.telegraph.co.uk/news/1526690/Animal-activists-freed-over-filthy-breedingcentre.html

Peet, Judy. "NJIT homeland security center studies groundbreaking anti-terrorism technology." NJ.com (June 12, 2010) http://www.nj.com/news/index.ssf/2010/06/njit_scientists_homeland_secur.html 
People for the Ethical Treatment of Animals. "Victory! Wyeth Closes Premarin Plant." (n.d) http://www.peta.org/features/wyeth-closes-premarin-plant.aspx

Piltz, Rick. "Sensenbrenner IPCC witch-hunt: Attempt to blacklist climate scientists must be rejected." Climate Science Watch (December 9, 2009)

http://www.climatesciencewatch.org/2009/12/09/sensenbrenner-ipcc-witch-hunt-attemptto-blacklist-climate-scientists-must-be-rejected/

Potter, Will. “The Green Scare.” Vermont Law Review 33 (2009): 671-689.

Priest, Dana and William M. Arkin. "Top Secret America.” Washington Post (July18-19, 2010) http://projects.washingtonpost.com/top-secret-america/

"Report to Congress on the Extent and Effects of Domestic and International Terrorism in Animal Enterprises." The Physiologist 36 no.6 (1993): 207, 247-259.

Roug, Louise. "Jim Inhofe gets cool reception in Denmark." Politico (December 19, 2009) http://www.politico.com/news/stories/1209/30769.html

Rowlands, Mark. Animals Like Us. London:Verso, 2002.

Schmid, Alex P. "Terrorism as Psychological Warfare.” Democracy and Security 1 (2005): 137-146.

"Sensenbrenner to Tell Copenhagen: No Climate Laws Until ‘Scientific Fascism' Ends.” Fox News (December 9, 2009) http://www.foxnews.com/politics/2009/12/09/sensenbrenner-climatefascism/

Shepherd, Kate. "James Inhofe's One-Man Truth Squad.” Mother Jones (December 17, 2009) http://motherjones.com/blue-marble/2009/12/inhofe-brings-one-man-truth-squad-0

Sourcewatch. "James M. Inhofe." (n.d.) http://www.sourcewatch.org/index.php?title=James_M._Inhofe

---. "NABR \& the Animal Welfare Act." (2011) http://www.sourcewatch.org/index.php?title=NABR_\%26_the_Animal_Welfare_Act

---. "Oregon National Primate Research Centre." (2011) http://www.sourcewatch.org/index.php?title=Oregon_National_Primate_Research_Center

---. “Ten Worst Laboratories.” (2011) http:/ /www.sourcewatch.org/index.php?title=Ten_Worst_Laboratories

SPEAK. "Bad Politics" (n.d.) http://speakcampaigns.org/sitepages.php?a=5

Stewart, Scott. "Escalating Violence From the Animal Liberation Front." Security Weekly (July 29, 2010) http://www.stratfor.com/weekly/20100728_escalating_violence_animal_liberation_front

Sundt, Nick. "WWF Climate Blog In Congressional Hearing, Administration Officials Respond to E-Mail Controversy." (January 7, 2009) http://www.wwfblogs.org/climate/content/congressional-hearing-administration-officialsrespond-e-mail-controversy

Thomas, Jo. “"No Sympathy' for Dead Children, McVeigh Says.” New York Times (March 29, 2001) http://www.nytimes.com/2001/03/29/us/no-sympathy-for-dead-children-mcveighsays.html

Toetz, Jeff. "Boss Hog." Rolling Stone (Feb. 14, 2007) http://www.rollingstone.com/politics/story/1 2840743/porks_dirty_secret_the_nations_top_hog_producer_is_also_one_of_americas_wor st_polluters 
Trull, Frankie, 2009. “Thirty Years ... Time Flies!” National Association for Biomedical Research (September 24, 2009)

http://www.nabr.org/AboutNABR/AskFrankie/tabid/952/EntryId/10/Thirty-years-TimeFlies.aspx

U.S. Department of State Office of the Coordinator for Counterterrorism. "Annex of Statistical Information to Country Reports on Terrorism." Washington, D.C.: National

Counterterrorism Center, 2007. http://www.state.gov/s/ct/rls/crt/2006/82739.htm

United States Senate Committee on Environment and Public Works. "Consensus' Exposed: The CRU Controversy.” Washington, D.C.: Minority Staff, February, 2010.

---. "Eco-terrorism Specifically Examining the Earth Liberation Front ("ELF") and the Animal Liberation Front ('ALF')" (May 18, 2005) http://www.rexano.org/Eco_terror_32209.pdf , 1

Ward, Simon. "Media Link September 11 With Ecoterror.” Fur Commission USA, 2001. http://www.furcommission.com/news/newsF03p.htm

Wilson, Graeme. "Sainsbury Quits 'in Anger over Loan Affair."” The Telegraph (November 11, 2006) http:/ /www.telegraph.co.uk/news/uknews/1533851/Sainsbury-quits-in-anger-at-loansaffair.html 